\title{
Działalność wydawnicza krakowskiego Oddziału Polskiej Akademii Nauk
}

Jednym z najważniejszych zadań postawionych przed krakowskim Oddziałem Polskiej Akademii Nauk była działalność wydawnicza. Niemal od samego początku prowadzono tutaj ożywioną działalność wydawniczą, która obejmowała druk „Rocznika Biblioteki PAN w Krakowie”, „Rocznika Oddziału PAN w Krakowie”, „Sprawozdań z posiedzeń Komisji”, "Nauki dla Wszystkich” oraz roczników poszczególnych komisji naukowych. „Roczniki Biblioteki PAN w Krakowie” zaliczyć możemy do najstarszych wydawnictw wspomnianego Oddziału. Jego pierwszy numer ukazał się już w 1955 r. Stał się on znakomitym źródłem historii krakowskiego ośrodka naukowego, świadczącym o jego określonej pozycji pisarskiej i wkładzie, jaki wniósł do polskiej nauki. „Sprawozdania z posiedzeń komisji naukowych" drukowane były od 1959 r. Zamieszczano w nich, w całości lub we fragmentach, referaty wygłaszane na posiedzeniach poszczególnych komisji. Seria popularnonaukowa „Nauka dla Wszystkich” ukazywała się od 1966 r., a jej głównym celem było szerokie upowszechnienie nauki. Dość często krótkie i popularnonaukowe opracowania były adresowane do uczniów, studentów, nauczycieli oraz licznego grona czytelników, które poszukiwało w nich interesującego omówienia niejednokrotnie trudnych i złożonych tematów naukowych.

Oddział PAN w Krakowie od pierwszych lat swojego istnienia należał do jednego z największych w kraju. W porównaniu z pozostałymi: gdańskim, katowickim, lubelskim, łódzkim, poznańskim i wrocławskim, miał rozwiniętą strukturę organizacyjną w stopniu najwyższym, co sytuowało go w gronie najlepiej działających. Swoim zasięgiem starał się obejmować obszar południowo-wschodniej

* Dr, Uniwersytet Pedagogiczny im. Komisji Edukacji Narodowej w Krakowie, Wydział Pedagogiczny, Instytut Pedagogiki Przedszkolnej i Szkolnej, Katedra Historii Oświaty i Wychowania, 30-060 Kraków, ul. Ingardena 4.

1 Za wydawanie „Rocznika Oddziału PAN w Krakowie” i „Sprawozdań z posiedzenia Komisji” odpowiedzialne było Prezydium Oddziału Polskiej Akademii Nauk w Krakowie. 
Polski, czyli obecnego województwa małopolskiego i podkarpackiego. Utworzono go w oparciu o ustawę o Polskiej Akademii Nauk z 30 października 1951 r., gdzie wyraźnie zaznaczono, że powstał on:

W celu zapewnienia nauce polskiej warunków wszechstronnego rozwoju i pełnego rozkwitu oraz nadania badaniom naukowym kierunku, odpowiadającego istotnym potrzebom Narodu, w oparciu o postępowe tradycje nauki, jako też o najlepsze osiągnięcia i doświadczenia wszystkich działających dotychczas instytucji naukowych, a w szczególności Polskiej Akademii Umiejętności i Towarzystwa Naukowego Warszawskiego - powołuje się Polską Akademię Nauk².

Zanim Oddział PAN w Krakowie rozpoczął swoją działalność minęło jeszcze kilka lat. Nastąpiło to dopiero w 1957 r., gdy zaczęła obowiązywać uchwała Prezydium Polskiej Akademii Nauk z dnia 18 grudnia:

Zgodnie z art. 10 pkt. 2 ustawy z dnia 30 października 1951 r. o Polskiej Akademii Nauk Prezydium Polskiej Akademii Nauk uchwala powołanie Oddziału Polskiej Akademii Nauk w Krakowie.

Dla sprecyzowania statutu Oddziału - zgodnie z wynikiem dyskusji nad projektem przedłożonym przez grupę krakowskich członków Prezydium PAN - powołuje się komisję w składzie: prof. Kazimierz Nitsch, Jan Dąbrowski, Aleksander Krupkowski, Stanisław Leszczycki, Maurycy Jaroszewski.

Komisja przedłoży projekt statutu Oddziału na posiedzeniu PAN w dniu 8 stycznia 1957 roku³.

Przywołana uchwała przesądziła ostatecznie o losach Polskiej Akademii Umiejętność i zakończyła kilkuletnie starania o jej ratowanie ${ }^{4}$. Były to ciężkie czasy dla Akademii, która od 1873 r. kontynuowała dzieło Towarzystwa Naukowego Krakowskiego i przetrwała niezwykle trudny dla nauki polskiej okres zaborów ${ }^{5}$. $Z$ perspektywy czasu wydaje się, że nieodwracalne decyzje o dalszym istnieniu Akademii zapadły już wcześniej. Decydującym było niewątpliwie uchwalenie wspomnianej wcześniej ustawy o PAN. Znalazł się tam jednoznaczny zapis mówiący o tym, że Polska Akademia Nauk powstaje, aby kontynuować prace prowadzone wcześniej przez działające na ziemiach polskich towarzystwa naukowe. Pomijając ówczesne wydarzenia polityczne, podkreślić należy, że krakowski Oddział PAN starał się raczej łączyć niż dzielić środowisko naukowe Krakowa. Poprzez odpowiednie działania zachęcał do coraz to intensywniejszych prac badawczych, w celu ich upowszechniania w kraju i za granicą. Od samego początku kierowali nim powszechnie uznani profesorowie, należący do grona najbardziej cenionych uczonych w Polsce, jak: Władysław Szafer, Marian Mięsowicz, Aleksander Krupkowski, Zenon Klemensiewicz i inni ${ }^{6}$. Przez wiele lat główną siedzibą Oddziału krakowskiego był budynek należący wcześniej do Polskiej Akademii Umiejętności, przy ulicy Sławkowskiej 17. Obecnie Oddział zajmuje pomieszczenia przy ul. św. Jana 28 w najstarszej części Krakowa.

2 Ustawa o Polskiej Akademii Nauk z 30 października 1951 (DzU 1951, nr 36, poz. 108).

3 „Rocznik Polskiej Akademii Nauk Oddział w Krakowie 1957/1958”, Kraków 1959, s. 49.

${ }^{4}$ P. Hübner, Siła przeciw rozumowi... Losy Polskiej Akademii Umiejętności latach 1939-1989, Kraków 1994, s. 159-278.

${ }^{5}$ D. Rederowa, Z dziejów Towarzystwa Naukowego Krakowskiego. Karta z historii organizacji nauki polskiej pod zaborami, Kraków 1998, s. 305.

${ }^{6}$ P. Milczanowski, Polska Akademia Nauk Oddział w Krakowie 1957-1997, Kraków 1997, s. 37 i s. $43-70$. 
Za prezentowaną tutaj działalność wydawniczą krakowskiego Oddziału odpowiedzialne było Prezydium i zespoły redakcyjne poszczególnych komisji. Z udziałem tych ostatnich, poprzez poszczególne czasopisma, starano się prezentować prace prowadzone w komisjach naukowych, o czym mogliśmy się przekonać, przeglądając chociażby pierwsze sprawozdanie prezesa prof. Władysława Szafera:

Komisje wydają już lub też wydawać będą od 1959 swoje własne publikacje, niektóre w języku polskim, inne w językach konferencyjnych. Jeszcze w roku bieżącym ukażą się niektóre z nich w swych pierwszych zeszytach a n: Folia Orientalna, Acta Biologia Cracoviensia i może Folia Medica Cracoviensia.

Komisja Pedagogiczna oddała do druku jedną z swych obszerniejszych prac. Szeroko zakrojonego planu wydawnictw komisyjnych na rok 1959, który przedłożono już do zatwierdzenia Wydziałowi i Prezydium Akademii.

Jak już wcześniej zasygnalizowano, prezentowana działalność wydawnicza w większości skupiała się na przedstawianiu aktualnego dorobku naukowego członków PAN i osób współpracujących z poszczególnymi komisjami. Przy opracowaniu redakcyjnym i druku publikacji krakowski Oddział wspierany był początkowo przez Wydawnictwo Ossolineum, gdzie istniała specjalnie powołana w tym celu redakcja naukowa. Od 1975 r. przy krakowskim Oddziale działa Sekcja Wydawnicza, do zadań której należało planowanie terminów poszczególnych wydawnictw, przyjmowanie do realizacji kompletnych tomów i przekazywanie ich do druku. W tym czasie zlecano to przeważnie Państwowemu Wydawnictwu Naukowemu i Zakładowi Narodowemu im. Ossolińskich. W 1994 r. powołano własne Wydawnictwo Oddziału PAN w Krakowie. W dużej mierze utworzono go w celu obniżenia kosztów ogólnych wydawanych czasopism oraz usprawnienia prac redakcyjnych, w tym przygotowywanie tekstów do druku. Powstały w oparciu o wspomniane zasady ośrodek wydawniczy miał własną poligrafię komputerową, zajmował się redakcją merytoryczną i techniczną wspomnianych wydawnictw oraz dokonywał ich składu i łamania.

W wydawanych przez Oddział czasopismach ciągłych prezentowano głównie własne badania naukowe organizowane w komisjach. Prowadzono je w bardzo szerokim zakresie i, co warto podkreślić, znacznie wykraczając poza istniejący już stan wiedzy. Osiągnięte w ten sposób wyniki miały też zastosowanie praktyczne. Osoby związane z Komisją Archeologiczną zorganizowały badania nad przedrozbiorowym Krakowem i średniowiecznym Przemyślem oraz dokonały inwentaryzacji kilku grodzisk południowej Polski. Zakrojone na dużą skalę wykopaliska w Dolinie Dunajca, Popradu oraz dorzeczu Sanu i Wisłoki poszukiwały śladów osadnictwa z okresu paleolitu, epoki brązu i żelaza. Wyniki tych terenowych prac zamieszczono w „Roczniku” „Acta Archaeologica Carpathica” i serii „Prace Komisji Archeologicznej". Komisja Historyczna zajmowała się stosunkami polsko-niemieckimi, polsko-czeskimi i polsko-ukraińskimi w kontekście zasobów źródłowych i kartografii historycznej. Prowadziła badania nad kodeksem dyplomatycznym, parlamentaryzmem polskim XVI i XVII w., genezą agresji hitlerowskiej na Polskę

7 Sprawozdanie z działalności Oddziału Polskiej Akademii Nauk w Krakowie za okres od lutego 1957 do czerwca 1958, „Rocznik Polskiej Akademii Nauk Oddział w Krakowie”, Kraków 1959, s. 29-30. 
i ruchem oporu w Polsce południowej. Ten bogaty materiał badawczy pokazano w seriach „Prace Komisji Historycznej”, „Materiały Komisji Historycznej” oraz kwartalniku „Studia Historyczne”. Niezwykle cenne były badania prowadzone przez Komisję Nauk Geograficznych w zakresie środowiska geograficznego miasta Krakowa i jego problemów społeczno-ekonomicznych. Wyniki tych prac wykorzystywane były przez Biuro Rozwoju Miasta Krakowa, Instytut Gospodarki Przestrzennej i Komunikacji i Urząd Miasta przy opracowaniu koncepcji rozwoju Krakowa. Do materiału tego można było dotrzeć za pośrednictwem „Folia Geographica”, „Seria Geographica-Physica” i „Folia Geographica”, „Seria Geographica-Oeconomica". W tej ostatniej starano się też przedstawić najważniejsze problemy demograficzno-osadnicze i społeczno-gospodarcze województwa małopolskiego w odniesieniu do nowego podziału administracyjnego kraju. Warto wspomnieć też o opracowaniach naukowych Komisji Urbanistyki i Architektury dotyczących urbanistyki i architektury Krakowa, rewaloryzacji zabytków i planowania przestrzennego, które wydrukowano w „Tece Komisji Urbanistyki i Architektury”.

Początkowo w krakowskim Oddziale działało sześć komisji naukowych (tabela 1). Bardzo szybko, bo już w roku następnym pojawiły się trzy nowe: Historycznoliteracka, na czele której stanął Zygmunt Czerny, Nauk Ekonomicznych z profesorem Feliksem Młynarskim i Nauk Technicznych, gdzie przewodniczącym został Aleksander Krupkowski. W obecnej strukturze organizacyjnej Oddziału istnieje ponad trzydzieści komisji oraz Ośrodek Dokumentacji Fizjograficznej.

Tabela 1. Komisje Naukowe działające w 1957 r. w krakowskim Oddziale PAN

\begin{tabular}{|c|l|l|c|}
\hline Lp. & \multicolumn{1}{|c|}{ Nazwa komisji } & \multicolumn{1}{|c|}{ Przewodniczący } & Liczba członków \\
\hline 1. & Archeologiczna & Stefan Nosek & 21 \\
\hline 2. & Nauk Biologicznych & Zygmunt Grodziński & 38 \\
\hline 3. & Nauk Historycznych & Jan Dąbrowski & 50 \\
\hline 4. & Nauk Medycznych & Tadeusz Tempa & 24 \\
\hline 5. & Nauk Pedagogicznych & Maksymilian Siemieński & 18 \\
\hline 6. & Orientalistyczna & Tadeusz Lewicki & 18 \\
\hline
\end{tabular}

Źródło: Sprawozdanie z działalności Oddziału Polskiej Akademii Nauk w Krakowie za okres od lutego 1957 do czerwca 1958, „Rocznik Polskiej Akademii Nauk Oddział w Krakowie", Kraków 1959, s. 29-30.

${ }^{8}$ Dzisiaj w Oddziale pracują 32 komisje i jeden zespół problemowy. Są to Komisje: Archeologiczna, Etnograficzna, Historyczna, Historycznoliteracka, Językoznawstwa, Nauk Ekonomicznych i Statystyki, Nauk, Organizacji i Zarządzania, Nauk Pedagogicznych, Nauk Prawnych, Nauk Psychologicznych, Orientalistyczna, Prasoznawcza, Słowianoznawstwa, Biologiczna, Budownictwa, Elektrotechniki, Informatyki i Automatyki, Mechaniki Stosowanej, Metalurgiczno-Odlewnicza, Motoryzacji, Nauk Ceramicznych, Urbanistyki i Architektury, Nauk Rolniczych i Leśnych, Technicznej Infrastruktury Wsi, Historii i Filozofii Medycznej, Nauk Medycznych, Geodezji i Inżynierii Środowiska, Gospodarki Wodnej, Nauk Geograficznych, Nauk Geologicznych, Nauk Mineralogicznych, Ergonomiczna, Ochrony Zdrowia Społecznego. 
Przez ponad pięćdziesiąt lat działalności komisji w ich pracach zauważyć można było wiele zmian. Na początku stosunkowo duży nacisk kładziono na wzajemną współpracę i rozwój naukowy w zakresie obranych specjalności. W spotkaniach, obok samodzielnych pracowników nauki, czynnie uczestniczyli też młodsi badacze, prezentujący swoje dokonania naukowe. Po wygłoszeniu referatów prowadzono długie dyskusje oraz zajmowano się kwalifikacją tekstów zgłoszonych do druku. Dzisiaj spotkania w komisjach wykraczają czasem poza ramy nakreślone wcześniej dla swojej podstawowej działalności. Podczas organizowanych spotkań, konferencji czy zebrań poruszane są różne problemy. Dla przykładu można wspomnieć o wystąpieniu dr. Marka Wrońskiego Z archiwum nierzetelności naukowej i prof. Stefana Kwiatkowskiego (przewodniczącego Komitetu Nauk Pedagogicznych PAN w Warszawie) Kwalifikacje a kompetencje nauczyciela.

Przy Oddziale krakowskim powołano liczne komitety i zespoły problemowe, które skupiały uczonych o wielostronnych zainteresowaniach, reprezentując różne środowiska naukowe. Podejmowano ważne tematy badawcze, nawiązując przy okazji współpracę z międzynarodowymi organizacjami naukowymi. W latach 19711993 działał Zespół Badawczy Dziejów Oświaty w Latach Okupacji Hitlerowskiej (1939-1945). W ramach prowadzonych badań przeprowadził wnikliwą kwerendę źródłową oraz zebrał bogate archiwum dokumentacji z działalności nauczycieli polskich biorących udział w tajnym nauczaniu na terenie tzw. dystryktu krakowskiego.

Wymienione tutaj badania o czasach okupacji hitlerowskiej polegały na gromadzeniu, a następnie publikowaniu zebranych materiałów. Wspomniane prace rozpoczęto już w 1958 r. i prowadzono w ścisłym porozumieniu z Zarządem Głównym oraz odpowiednimi Zarządami Okręgowymi Związku Nauczycielstwa Polskiego. Działająca przy Zarządzie Głównym w Warszawie Komisja do Badań Dziejów Oświaty i Wychowania wyraziła zgodę na wyodrębnienie zbioru tzw. dystryktu krakowskiego i zezwoliła na jego opracowanie przez krakowski Oddział PAN. Jak szeroko zakrojone były to działania może świadczyć fakt, że ZNP Okręgów Krakowskiego i Rzeszowskiego zobowiązały podległe sobie jednostki do gromadzenia i przekazania odezw, kwestionariuszy, okólników oraz wszelkiej korespondencji. Oceniając zebrane materiały, można stwierdzić, że miały one różnoraką wartość historyczną. Przyczyniły się do powstania trwałego śladu tej niezwykle bogatej działalności konspiracyjnej. Prace wspomnianego zespołu w jego początkowym okresie polegały na:

Wyszukiwaniu ludzi, którzy brali czynny udział w pracach tajnych polskich władz oświatowych lub w tajnym nauczaniu, nawiązywano z nimi kontakty, skłaniając ich do nadsyłania sprawozdań, wspomnień, dokumentów, zdjęć, do udzielania wyjaśnień itp. W związku z tym podjęto liczne wyjazdy $w$ teren $^{9}$.

Był to bogaty materiał obejmujący osobiste wspomnienia uczestników tajnego nauczania, sprawozdania byłych tajnych władz oświatowych i niewielkie opracowania na temat dziejów oświaty oraz tajnego nauczania w poszczególnych

9 W. Gałecki, Oświata w latach okupacji. Informacje wstępne, „Rocznik Komisji Nauk Pedagogicznych”, Materiały do dziejów oświaty w okresie okupacji hitlerowskiej (1939-1945) na terenie dystryktu krakowskiego, t. 1, Wrocław-Warszawa-Kraków, 1961, s. 3-4. 
powiatach. Z dużą starannością zebrano i opracowano ten obszerny materiał, a następnie zamieszczono go w kilku tomach „Rocznika Komisji Nauk Pedagogicznych”. Wspomniany „Rocznik” zatytułowano Materiały do dziejów oświaty w okresie okupacji hitlerowskiej 1939-1945 na terenie dystryktu krakowskiego ${ }^{10}$. Jego pierwszym redaktorem naukowym został Włodzimierz Gałecki, a redaktorem wydania Marian Tyrowicz. Numer ten w 1961 r. wydrukował Zakład Narodowy im. Ossolińskich, Wydawnictwo Polskiej Akademii Nauk Wrocław-WarszawaKraków. Po czterech latach zmieniono nieco charakter przywołanego „Rocznika”, poszerzając problematykę historyczną o tematy pedagogiczne. Powołano nowy Komitet Redakcyjny, którego przewodniczącym został Maksymilian Siemieński, sekretarzem Jan Kulpa, a członkami: Kazimierz Dąbrowski, Włodzimierz Gałecki, Ignacy Zarębski ${ }^{11}$.

Z czasem Zespół Badawczy Dziejów Oświaty w Latach Okupacji Hitlerowskiej zasięgiem własnych badań objął też województwo kieleckie, rzeszowskie i katowickie oraz niektóre obszary Polski przedwrześniowej, w tym Wilno i Lwów. Zgromadzone dokumenty, wspomnienia i relacje pozwoliły opracować Słownik nauczycieli Ziemi Krakowskiej i Słownik ofiar wojny i członków ruchu oporu 1939. Wysoko oceniano prace wspomnianego zespołu, zwłaszcza w zakresie gromadzenia i weryfikacji zaświadczeń o uczestnictwie nauczycieli w tajnym nauczaniu. Wspólnie z Główną Komisją Badania Zbrodni Hitlerowskich w Polsce ustalono pełny stan strat wojennych wśród nauczycieli na południu naszego kraju.

Od 1958 r. ukazywał się „Rocznik Oddziału Polskiej Akademii Nauk w Krakowie", który w przeważającej części miał charakter faktograficzny. Posiadał dość ściśle określoną strukturę, którą otwierała część informacyjna, zawierająca skład osobowy Prezydium Oddziału, wykaz członków zamieszkujących na terenie Oddziału oraz członków poszczególnych komisji naukowych. W dalszej części zamieszczano najważniejsze uchwały Prezydium Oddziału, zmiany w jej strukturze, sprawozdania z okolicznościowych sesji naukowych i wyjazdowych posiedzeń oraz działalność popularyzatorską (np. o publicznych odczytach). Prowadzono też kronikę, w której omawiano sprawy osobowe, w tym także zmiany we władzach i powołania nowych członków. Dość często zamieszczano tutaj nekrologi i informacje o zmarłych członkach Oddziału oraz członkach komisji naukowych ${ }^{12}$.

${ }^{10}$ Pod wspomnianym tytułem ukazał się tom I, II, III, VI, VIII. Tom XI zatytułowano Materiały do dziejów oświaty w okresie okupacji hitlerowskiej (1939-1945) na terenie podziemnego Okręgu Szkolnego Krakowskiego. Tom ten był szóstym w kolejności i różnił się od pozostałych ze względu na problemowe ujęcie zagadnień w odniesieniu do całego dystryktu. Zamieszczono w nim wspomnienia Adama Przybosia o Włodzimierzu Gałeckim i przemówienie żałobne Wincentego Danka wygłoszone podczas pogrzebu W. Gałeckiego.

${ }^{11}$ Od tomu piątego „Rocznik Komisji Nauk Pedagogicznych” ukazuje się jako czasopismo pedagogiczne, przygotowywany jest przez Komitet Redakcyjny. Przez wiele lat w jego składzie zasiadał Zygmunt Ruta i Jan Krukowski. Ostatnio w pracach redakcyjnych czynnie uczestniczy Stanisław Palka.

12 Źródłem do opracowania tej części „Rocznika” były protokoły posiedzeń Prezydium Oddziału, dokumentacja poszczególnych komisji naukowych, uchwały władz, roczniki czasopism i wycinki prasowe. 
Całość zamykała pełna bibliografia wydawnictw Oddziału PAN w Krakowie, poszerzona o szczegółowe zestawienie zawartości miejscowych czasopism oraz publikowanych sprawozdań. W ostatnim okresie ukazywał się on nieregularnie. W 2011 r. wydano tom obejmujący lata 2007-2010. Poprzednie tomy również obejmowały kilka lat tj. 2003-2006 i 1989-2002. Mogły być one drukowane w dużej mierze dzięki wsparciu finansowemu Komitetu Badań Naukowych i Ministerstwa Nauki i Szkolnictwa Wyższego.

Tabela 2. Treść pierwszego tomu „Rocznika Polskiej Akademii Nauk Oddział w Krakowie”

\begin{tabular}{|c|c|}
\hline Spis treści & Strony \\
\hline Skład Oddziału Polskiej Akademii Nauk w Krakowie ..................... & 5 \\
\hline Nekrologi ....... & 6 \\
\hline Komisje naukowe ........................ & 7 \\
\hline 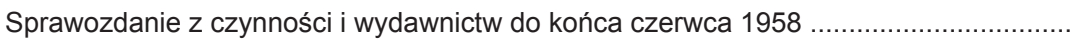 & 14 \\
\hline Posiedzenie publiczne dnia 13 czerwca 1958 & \\
\hline 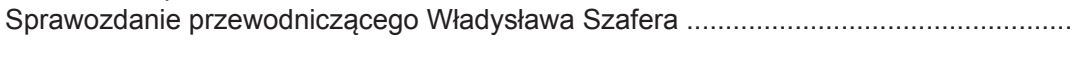 & 22 \\
\hline Zenon Klemensiewicz: Udział językoznawstwa w rozwoju języka .............................. & 35 \\
\hline 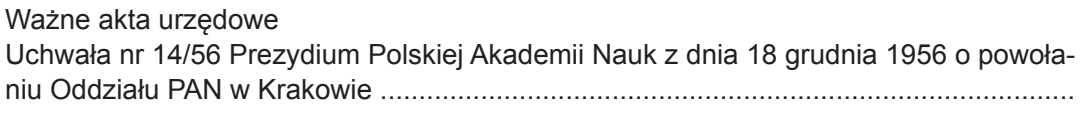 & 49 \\
\hline 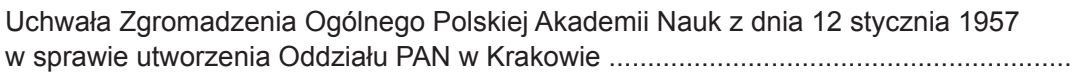 & 49 \\
\hline Tymczasowy statut Oddziału PAN w Krakowie .... & 50 \\
\hline
\end{tabular}

Źródło: „Rocznik Polskiej Akademii Nauk Oddział w Krakowie 1957/1958”, Kraków 1959.

Materiały prezentowane w „Roczniku” miały nie tylko dużą wartość informacyjną, ale także poznawczą. Zawierały wiele treści bieżących i aktualnych oraz rozległą tematykę badawczą prowadzoną przez komisje. Za jego pośrednictwem prezentowano szerszemu ogółowi referaty naukowe czy wystąpienia programowe wygłoszone na corocznych walnych zebraniach Akademii. Niezwykle cenną była zawarta w nim bibliografia wydawnictw.

Od 1959 r. systematycznie drukowane są „Sprawozdania z Posiedzeń Komisji Naukowych". Były one ważnym wydawnictwem krakowskiego Oddziału PAN, gdzie w całości bądź w formie streszczeń zamieszczano wystąpienia przedstawiane na posiedzeniach komisji naukowych. Ostatni tom tych sprawozdań ukazał się w numerze XLVII/1 i obejmował okres od stycznia do czerwca $2003 \mathrm{r}$. Zaprezentowano w nim sprawozdania z prac w siedmiu wydziałach Oddziału, Komisji Międzywydziałowej oraz Komisji Ochrony Zdrowia Społecznego ${ }^{13}$.

${ }^{13}$ W Komisji Nauk Pedagogicznych zaprezentowano dwa bardzo ciekawe wystąpienia: J. Kuźmy, Rozwój edukacji komparatystycznej oraz H. J. Hirscha, Prawo karne czyn - czy rzeczywistość. 
Z działalnością Biblioteki krakowskiego Oddziału Polskiej Akademii Nauk związany był „Rocznik Biblioteki PAN w Krakowie”, w którym starano się ukazać opracowania własnych zbiorów oraz zaprezentować posiadane księgozbiory i zbiory specjalne. W prezentowanych tutaj pracach naukowo-edytorskich starano się nawiązać do pierwszego katalogu zbiorów rękopiśmiennych, jeszcze z okresu Biblioteki Towarzystwa Naukowego Krakowskiego, który został wydany w 1869 r. przez Władysława Seredyńskiego ${ }^{14}$. W wyniku prac nad zbiorami specjalnymi omówiono poszczególne spuścizny i zespoły rękopisów, katalogi atlasów i map XVI-XVIII w., zbiory luźnych pieczęci, katalogi obrazów oraz rzeźb i rycin ze zbiorów Polskiej Akademii Umiejętności. Stałą pozycją „Roczników” były roczne sprawozdania z działalności Biblioteki, gdzie dość szczegółowo przedstawiano jej pracę. Sprawozdania te uznać należy za niezwykle cenny materiał dokumentacyjny i statystyczny przedstawiający w miarę pełny obraz dokonań Biblioteki.

Od 1966 r Oddział krakowski prowadził popularnonaukową działalność wydawniczą poprzez serię „Nauka dla Wszystkich”. W ramach niej ukazało się wiele krótkich i zwięzłych opracowań przeznaczonych dla uczniów, studentów, nauczycieli i bliżej nieokreślonego czytelnika, pragnącego poszerzyć swoją wiedzę z różnych dziedzin nauki. Autorami poszczególnych numerów były uznane osoby w krakowskiej nauce, takie jak: W. Szafer Dziesięć tysięcy lat historii lasów ciągłych Tatrach (nr 1), Z. Klemensiewicz Rys dziejów języka polskiego (nr 29), S. Pigoń Wprowadzenie w Pana Tadeusza (nr 90), J. Wyrozumski Kazimierz Wielki i jego dzieło (1333-1370) (nr 156), J. Jarowiecki Prasa konspiracyjna w Krakowie (1939-1945) (nr 251), A. Manecki Meteoryty, pyły kosmiczne i skały księżycowe (nr 251), J. Vetulani Dzień dzisiejszy i jutro neurobiologii (391). Przez blisko czterdzieści lat jej propagowania wydano 486 różnego rodzaju pozycji.

W podsumowaniu ponad pięćdziesięcioletniej działalności wydawniczej krakowskiego Oddziału PAN stwierdzić należy, że dorobek ten jest niezwykle duży ${ }^{15}$. W omawianym okresie poszczególne komisje naukowe i różnego rodzaju zespoły badawcze doprowadziły do wydania ponad 50 tytułów czasopism naukowych. Z inicjatywy Prezydium Oddziału ukazały się 33 tomy „Rocznika” oraz 67 tomów sprawozdań z posiedzeń komisji naukowych. Nie oznaczało to, że prace te przebiegały bez zakłóceń. Całkiem nieźle pod tym względem wyglądały lata sześćdziesiąte i siedemdziesiąte, kiedy wysokie dotacje państwowe pozwalały na realizację prawie całego planu wydawniczego. Pierwsze trudności z finansowaniem wszystkich tytułów pojawiły się już pod koniec lat osiemdziesią-

${ }^{14}$ W. Seredyński, Rękopisy Towarzystwa Naukowego systematycznie zestawione, Kraków 1869.

${ }^{15} \mathrm{~W}$ prezentowanym opracowaniu nie będziemy zajmować się niezwykle bogatym dorobkiem wydawniczym Oddziału obejmującym opracowania zwarte oraz monografie. W miarę pełne informacje na ten temat można uzyskać za pośrednictwem „Rocznika Polskiej Akademii Nauk Oddział w Krakowie”, w części poświęconej zestawieniom bibliograficznym. 
tych i w latach dziewięćdziesiątych. Do najtrudniejszych należał jednak ostatni okres, kiedy sytuacja finansowa krakowskiego Oddziału PAN przedstawiała się, delikatnie mówiąc, nie najlepiej. Jego bilans zadłużenia na koniec 2009 r. znacznie przekraczał połowę kwoty potrzebnej na jego bieżącą działalność. Wśród niewykonanych należności znalazły się zobowiązania do ZUS, wypłaty dla pracowników, niezapłacone należności dla drukarni i redaktorów wydawnictw. Z sytuacją tą musiał zmierzyć się nowo wybrany prezes prof. Ryszard Tadeusiewicz, który rozpoczął swoje urzędowanie od wystosowania dość dramatycznego apelu do wszystkich przewodniczących komisji naukowych (w maju 2010 r.):

List ten kieruję do wszystkich PT Przewodniczących Komisji PAN zgrupowanych w Krakowskim Oddziale Akademii w związku z potrzebą poinformowania Państwa o aktualnym stanie Oddziału, o warunkach w jakich przez pewien czas muszą działać Komisje i o działaniach, jakie podejmuję, żeby Oddziałowi przywrócić zdolność do sprawowanego działania a komisjom warunki do normalnej pracy.

[...] Niezwłocznie zainteresowałem się między innymi stanem finansowym Oddziału, a dokładniej mówiąc - stanem finansowym tak zwanego Zakładu Działalności Pomocniczej (ZDP) obsługującego Oddział ${ }^{16}$.

Wspólnie z prezesem Michałem Kleiberem, dyrektorem Kancelarii Dariuszem Jadowskim i dyrektorem Biura Zarządzania Majątkiem PAN Grażyną Paruszewską-Wysińską postanowiono wprowadzić program naprawczy. Polegał on na zdecydowanym ograniczeniu wydatków, zlikwidowaniu nieefektywnych działów oraz niepotrzebnych stanowisk. Przestał istnieć Zakład Działalności Pomocniczej, a wszelkie sprawy związane z drukiem czasopism postanowiono przenieść do Warszawy. Komitetom Redakcyjnym pozostawiono decyzję o zawartości przygotowywanych numerów oraz ich opracowanie edytorskie. W celu utrzymania w miarę ciągłej działalności wydawniczej, z inicjatywy prezesa R. Tadeusiewicza, uruchomiono portal Internetowy ${ }^{17}$.

Okres zagrożonej działalności wydawniczej udało się pomyślnie przezwyciężyć i obecnie w gestii Oddziału pozostaje 21 wydawnictw ciągłych i 16 seryjnych ${ }^{18}$. Z wymienionych dwudziestu czasopism pięć posiada określoną pozycję międzynarodową. Wymienić w tym miejscu należy: „Acta Archaeologica Carpathica”, „Archiwum luridicum Cracoviense”, „Folia Orientalna”, „Acta Biologia Cracoviensia”, „Studia Geomorphologica Carpatho-Balcanica”"19.

${ }^{16}$ Fragment pisma prezesa Krakowskiego Oddziału PAN wystosowanego do przewodniczących komisji naukowych. W zbiorach autora.

17 http://www.pan-krakow.pl/komisje/

18 http://www.krakow.pan.pl/wydawnictwa/

${ }^{19}$ Krakowski oddział PAN w miarę możliwości finansowych stara się też wydawać serie. Są to: „Prace Komisji Archeologicznej”, „Prace Komisji Historycznej”, „Materiały Komisji Historycznej”, „Prace Komisji Historycznoliterackiej”, „Prace Komisji Językoznawstwa”, „Prace Komisji Orientalistycznej”, „Prace Komisji Słowianoznawstwa”, „Prace Komisji Mechaniki Stosowanej - Mechanika”, „Prace Komisji Metalurgiczno-Odlewniczej - Metalurgia”, „Prace Komisji Nauk Ceramicznych - Ceramika”, „Polski Biuletyn Ceramiczny”, „Prace Komisji Nauk Medycznych”, „Prace Komisji Geodezji i Inżynierii Środowiska - Geodezja”, „Prace Geologiczne” i „Prace Mineralogiczne”. 
Tabela 3. Wydawnictwa ciągłe Oddziału Polskiej Akademii Nauk w Krakowie w 2012 r.

\begin{tabular}{|c|l|l|c|}
\hline Lp. & \multicolumn{1}{|c|}{ Tytuł czasopisma } & \multicolumn{1}{|c|}{$\begin{array}{c}\text { Nazwa Komisji } \\
\text { Oddziału PAN }\end{array}$} & $\begin{array}{c}\text { Rok } \\
\text { powołania }\end{array}$ \\
\hline 1. & Acta Archaeologica Carpathica & Komisja Archeologiczna & 1959 \\
\hline 2. & Historyka. Studia Metodologiczne & Komisja Historyczna & 1967 \\
\hline 3. & Studia Historyczne & Komisja Historyczna & 1958 \\
\hline 4. & Ruch Literacki & Komisja Historycznoliteracka & 1960 \\
\hline 5. & Folia Oeconomica Cracoviensia & Komisja Nauk Ekonomicznych & 1960 \\
\hline 6. & Rocznik Komisji Nauk Pedagogicznych & Komisja Nauk Pedagogicznych & 1961 \\
\hline 7. & Archiwum luridicum Cracoviense & Komisja Nauk Prawnych & 1968 \\
\hline 8. & Folia Orientalna & Komisja Orientalistyczna & 1959 \\
\hline 9. & Rocznik Historii Prasy Polskiej & Komisja Prasoznawcza & \\
\hline 10. & Acta Biologia Cracoviensia, Seria Botanica & Komisja Biologiczna & 1958 \\
\hline 11. & Acta Biologia Cracoviensia, Seria Zoologia & Komisja Biologiczna & 1959 \\
\hline 12. & Teka Komisji Motoryzacji & $\begin{array}{l}\text { Komisja Naukowo-Problemowa } \\
\text { Motoryzacji }\end{array}$ & 1988 \\
\hline 13. & Teka Komisji Urbanistyki i Architektury & $\begin{array}{l}\text { Komisja Nauk Urbanistyki } \\
\text { i Architektury }\end{array}$ & 1968 \\
\hline 14. & Akta Agraria et Silvestria, Seria Agraria & $\begin{array}{l}\text { Komisja Nauk Rolniczych } \\
\text { i Leśnych }\end{array}$ & 1961 \\
\hline 15. & Akta Agraria et Silvestria, Seria Silvestris & $\begin{array}{l}\text { Komisja Nauk Rolniczych } \\
\text { i Leśnych }\end{array}$ & 1961 \\
\hline 16. & Akta Agraria et Silvestria, Seria Zootechnic & $\begin{array}{l}\text { Komisja Nauk Rolniczych } \\
\text { i Leśnych }\end{array}$ & 1961 \\
\hline 17. & Folia Medica Cracoviensia & Komisja Nauk Medycznych & 1959 \\
\hline 18. & Folia Geographica, Seria Geographica-Physica & Komisja Nauk Geograficznych & 1968 \\
\hline 19. & $\begin{array}{l}\text { Folia Geographica, Seria Geographica-Oeco- } \\
\text { nomica }\end{array}$ & Komisja Nauk Geograficznych & 1969 \\
\hline 20. & Studia Geomorphologica Carpatho-Balcanica & Komisja Nauk Geograficznych & 1967 \\
\hline & & & \\
\hline
\end{tabular}

Źródło: http:// www.krakow.pan.pl oraz informacje uzyskane w Oddziale PAN w Krakowie.

Jedną z propozycji na drodze do rozwiązania problemu niewystarczającego finansowania wydawnictw może być ich wspólne wydawanie z uczelniami lub innymi instytucjami naukowymi. Współpracę taką podjęto z Uniwersytetem Jagiellońskim i Uniwersytetem Pedagogicznym im. Komisji Edukacji Narodowej w Krakowie. Od dwóch lat PAN i UP w Krakowie wydaje „Rocznik Komisji Nauk Pedagogicznych” i „Rocznik Historii Prasy Polskiej”. Zgodnie z podpisanym porozumieniem Polska Akademia Nauk i Uniwersytet Pedagogiczny w Krakowie zobowiązały się do wzajemnego finansowania wspomnianych tytułów i ich systematycznego wydawania ${ }^{20}$.

${ }^{20}$ Umowa o wspólne wydawanie „Rocznika Komisji Nauk Pedagogicznych” Oddział w Krakowie i Umowa o wspólne wydawanie „Rocznika Historii Prasy Polskiej”. Archiwum autora. 